\title{
ANALISIS FENOMENA JANUARY EFFECT PADA SAHAM SEKTOR PERTAMBANGAN YANG TERDAFTAR DI BURSA EFEK INDONESIA (BEI)
}

\author{
INDRAYANI
}

Fakultas Ekonomi dan Bisnis, Universitas Malikussaleh, Lhokseumawe

This study aims to analyze the January Effect phenomenon based on the presence or absence of significant difference between the 5-days average abnormal return in the end of December and 5 days in early January on mining stocks listed on the Indonesia Stock Exchange during the period 2011-2015. The January effect is the tendency of rising stock prices between 31 December to the end of the first week in January. The population of this study is 41 companies and the samples are $35 \mathrm{com}$ panies taken using purposive sampling technique. The data used are secondary data in the price of the daily closing of stocks and JCI during the observation period. Data analysis method used is descriptive statistical analysis. The hypothesis testing is conducted using non-parametric difference test which is called as WilcoxonSigned Rank Test. The results showed that there is a significant difference between the 5-days average abnormal return in the end of December and 5 days in early January on mining stocks listed on the Indonesia Stock Exchange during the period 2011-2015, so the January Effect phenomenon has occurred.

Keywords: January Effect, Average Abnormal Return 


\section{PENDAHULUAN}

Pasar modal merupakan suatu sarana penting dalam perekonomian yang berfungsi memobilisasi dana dari masyarakat ke sektor produktif. Perusahaan sebagai pihak yang membutuhkan dana dapat menghimpun dana melalui pasar modal dengan menjual sahamnya kepada publik atau menerbitkan surat hutang, sedangkan investor sebagai pihak yang memiliki dana dapat mempergunakan pasar modal sebagai salah satu alternatif investasi guna memperoleh keuntungan.

Investasi yang efektif dilakukan adalah pada pasar modal efisien. Menurut Fahmi (2012: 215) pasar efisien (market efficient) adalah suatu kondisi dimana informasi tentang semua harga dapat diperoleh secara terbuka dan cepat tanpa ada hambatan khusus. Dalam melakukan investasi saham, seorang investor selalu mengharapkan adanya return atau keuntungan. Return saham adalah tingkat keuntungan yang dinikmati oleh pemodal atas suatu investasi yang dilakukannya (Robert Ang, 2001 dalam Prasetyo, 2006).

Pada pasar yang efisien, pasar akan cepat bereaksi terhadap informasi baru yang masuk sehingga pasar akan dengan cepat pula mencapai harga keseimbangan yang baru. Pada pasar yang efisien tidak ada kemungkinan memperoleh tingkat pengembalian abnormal (Pratomo, 2007). Sedangkan pada kenyataannya, tujuan para investor berinvestasi adalah untuk memperoleh return yang tinggi atau abnormal return. Abnormal return adalah return yang didapat investor yang tidak sesuai dengan pengharapan. Abnormal return adalah selisih antara return yang diharapkan dengan return yang didapatkan. Abnormal return dapat terjadi pada beberapa kondisi di pasar modal yang mengalami anomali/penyimpangan.

Gumanti (2011) dalam Purwati (2015) mengungkapkan bahwa anomali pasar adalah bukti yang menolak atau setidak tidaknya kurang mendukung keberadaan teori pasar efisien yang muncul pada semua bentuk pasar efisien baik itu lemah, semi kuat maupun kuat yang bisa dieksploitasi untuk menghasilkan abnormal return.

Dalam dunia investasi saham, ada satu fenomena mengenai kenaikan harga saham pada bulan Januari, yang dikenal dengan istilah January ef- fect. January effect adalah kecenderungan naiknya harga saham antara tanggal 31 Desember sampai dengan akhir minggu pertama pada bulan Januari (Yani, 2013). Pada bulan Januari diperkirakan investor akan memperoleh kesempatan untuk mendapatkan return yang lebih tinggi dibandingkan dengan bulan-bulan lainnya. Tingginya return pada bulan Januari ini terjadi karena adanya tekanan jual yang terjadi pada bulan Desember. Pada bulan Januari mereka kembali melakukan investasi sehingga terjadi tekanan beli yang mengakibatkan harga saham meningkat (Pratomo, 2007).

January effect bisa ditunjukkan dengan adanya return tidak normal yang diperoleh dari investor. Apabila suatu pengumuman mengandung informasi, pasar diharapkan dapat bereaksi terhadap informasi tersebut. Reaksi ini dapat diukur dengan menggunakan abnormal return. Apabila abnormal return digunakan maka dapat dikatakan bahwa suatu pengumuman yang mengandung informasi akan memberikan abnormal return kepada pasar. Dengan kata lain apabila January effect terjadi maka investor dapat menikmati $a b$ normal return (Lukmansyah, 2015). Dari keseluruhan perusahaan yang terdaftar di Bursa Efek Indonesia, peneliti memfokuskan kepada perusahaan sektor pertambangan. Pada penelitian ini periode pengamatan yang digunakan adalah selama 11 hari, terdiri dari 5 hari di akhir Desember ( $\mathrm{t}-5)$, hari saat pergantian tahun yaitu 1 Januari, dikarenakan tanggal 1 Januari adalah libur nasional dan harga saham tidak diposting, maka tanggal 2 Januari dijadikan sebagai hari kejadian (t0) dan 5 hari di awal Januari $(t+5)$. Waktu 11 hari ini diambil karena dianggap bahwa periode tersebut diharapkan dapat mencerminkan reaksi pasar. Jika periode peristiwa yang diambil terlalu singkat, maka dikhawatirkan adanya reaksi pasar yang cukup lama namun tidak dapat terdeteksi pada penelitian yang dilakukan, dan jika periode peristiwa yang diambil terlalu lama, dikhawatirkan adanya peristiwa lain yang cukup signifikan mempengaruhi hasil penelitian (Rafela, 2016). Berikut ini disajikan rata-rata harga saham pada 5 hari di akhir Desember dan 5 hari di awal Januari selama peiode 2011-2015. 
Tabel 1

Rata-Rata Harga Saham

\begin{tabular}{|l|c|c|r|r|}
\hline \multicolumn{1}{|c|}{ Rentang Waktu } & Des & Jan & Perubahan & Persentase \\
\hline Des 11 - Jan 12 & $3.222,38$ & $3.328,64$ & 106,27 & $3 \%$ \\
\hline Des 12 - Jan 13 & $2.752,02$ & $2.908,32$ & 156,30 & $6 \%$ \\
\hline Des 13 - Jan 14 & $2.118,36$ & $2.000,37$ & $-117,99$ & $-6 \%$ \\
\hline Des 14 - Jan 15 & $1.687,11$ & $1.646,53$ & $-40,58$ & $-2 \%$ \\
\hline
\end{tabular}

Sumber: Data Sekunder (diolah), 2017

Tabel di atas menunjukkan terjadinya pertumbuhan dari tahun sebelumnya sebagai tahun dasar yaitu bulan Desember 2011 sebesar 3.222,38 yang kemudian mengalami kenaikan pada bulan Januari 2012 sebesar 3.328,64 dengan persentase kenaikan sebesar 3\%. Lalu pada bulan Desember 2012 sebesar 2.752,02 yang juga mengalami kenaikan pada bulan Januari 2013 sebesar 2.908,32 dengan persentase kenaikan sebesar $6 \%$. Selanjutnya pada bulan Desember 2013 sebesar 2.118,36 namun kemudian mengalami penurunan pada bulan Januari 2014 menjadi sebesar 2.000,37 dengan persentase penurunan sebesar 6\%. Dan pada bulan Desember 2014 sebesar 1.687,11 yang juga kembali mengalami penurunan pada bulan Januari sebesar 1.646,53 dengan persentase penurunan sebesar $2 \%$.

Berdasarkan tabel di atas terlihat bahwa harga saham perusahaan pertambangan selama tahun 2011-2015 yang menunjukkan pergerakan harga saham dengan persentase yang mengalami kenaikan di bulan Januari yaitu pada tahun 2012 dan 2013 yang bisa memicu terjadinya January effect dan mengalami penurunan di bulan Januari tahun 2014 dan 2015 yang tidak memicu terjadinya January effect pada tahun tersebut. Dalam dunia investasi dengan adanya kenaikan harga saham pada bulan Januari maka dapat memicu terjadinya January effect.

Penelitian ini bertujuan untuk menganalisis fenomena January Effect berdasarkan ada tidaknya perbedaan yang signifikan antara rata-rata $a b$ normal return 5 hari di akhir Desember dan 5 hari di awal Januari pada saham sektor pertambangan yang terdaftar di Bursa Efek Indonesia selama periode 2011-2015.

\section{TINJAUAN PUSTAKA}

\section{Saham}

Dahlan Siamat (2001) dalam Syari (2012) menyatakan bahwa saham atau stock adalah surat bukti atau tanda kepemilikan bagian modal pada suatu perseroan terbatas. Transaksi jual beli bursa efek, saham sering pula disebut shares merupakan instrumen yang paling dominan diperdagangkan.

\section{Anomali Pasar Efisien}

Menurut Wulandari (2014) anomali adalah kejadian yang tidak dapat diantisipasi yang menawarkan peluang investor untuk memperoleh abnormal return. Levy (1996) dalam Prasetyo (2006) sedikitnya dikenal empat macam anomali pasar dalam teori keuangan, keempat anomali tersebut adalah anomali peristiwa atau kejadian (event anomalies), anomali musiman (seasonal anomalies), anomali perusahaan (firm anomalies) dan anomali akuntansi (accounting anomalies).

\section{January Effect}

January effect merupakan kecenderungan terjadinya kenaikan harga saham pekan pertama bulan Januari. Adanya kenaikan harga ini didorong oleh aktivitas investor untuk kembali menyusun portofolionya setelah mereka "terbenam" selama liburan akhir tahun. Permintaan investor yang meningkat terhadap instrumen keuangan inilah yang menyebabkan harga mengalami kenaikan. Kenaikan permintaan ini didorong oleh ekspektasi investor yang positif. January effect ini sering juga disebut dengan year end effect. Anomali ini menunjukkan bahwa terdapat kecenderungan bahwa keuntungan saham akan menurun pada bulan Desember dan kemudian akan meningkat pada 
awal Januari (Werastuti, 2012).

Andreas dan Ria Daswan (2011) dalam Tasman dkk (2015) menyatakan bahwa January effect merupakan salah satu bentuk anomali kalender dalam tahun atau biasa disebut month of the year effect. Return saham dikatakan cenderung naik di minggu-minggu awal bulan Januari. Yani (2013) menjelaskan bahwa January effect adalah kecenderungan naiknya harga saham antara tanggal 31 Desember sampai dengan akhir minggu pertama pada bulan Januari. January effect merupakan kecenderungan rata-rata return saham pada bulan Januari lebih tinggi dibandingkan bulanbulan lainnya (Pratomo, 2007).

January effect pertama kali diamati sekitar tahun 1942 oleh seorang banker bernama Sidney B. Wachtel, yang menyatakan bahwa ada kecenderungan performa saham yang tidak aktif meningkat tajam pada bulan Januari. Beberapa teori mengatakan fenomena ini terjadi karena investor retail di Amerika Serikat, yang memiliki saham yang tidak aktif ini, menjual sahamnya dengan alasan pajak pada akhir tahun dan menginvestasikan dananya pada awal tahun. Teori lainnya mengatakan bahwa adanya pembagian bonus di Amerika Serikat yang biasanya dibagikan di Januari, membuat investor banyak membeli saham di Januari sebagai investasi yang membuat harga saham naik.

Ada beberapa penyebab yang memungkinkan terjadinya anomali perilaku saham pada bulan Januari, seperti yang dikatakan oleh Sharpe (1995) dalam Pratomo (2007), yaitu:

a. Tax Loss Selling

Penjelasan paling populer berkaitan dengan efek Januari adalah hipotesis tax-loss selling dimana investor menjual saham yang nilainya turun. Hal ini dimaksudkan untuk menghasilkan tax loss sebelum akhir tahun atau mengurangi jumlah pajak yang ditanggungnya. Saham-saham yang mengalami tekanan jual ini akan mengalami penurunan harga pada bulan Desember dan akan meningkat kembali pada bulan Januari.

b. Window Dressing

Window dressing yaitu terjadinya aksi jual pada saham-saham yang memiliki kinerja buruk di akhir tahun. Window dressing ini tidak jauh berbeda dengan tax loss selling, perbedaannya adalah hal ini dilakukan oleh manajer keuangan dengan tujuan agar laporan kinerja portofolio saham yang dilaporkannya pada akhir tahun akan tampak bagus kinerjanya

\section{c. Small Stock's Beta}

Saham dengan kapitalisasi pasar kecil memiliki resiko yang lebih besar pada bulan Januari daripada pada bulan-bulan lainnya. Bila hal tersebut benar maka saham kapitalisasi kecil tersebut akan memiliki rata-rata return yang relatif lebih tinggi pada bulan Januari dibandingkan dengan bulan-bulan lainnya.

\section{d. Return Saham}

Menurut Tandelilin (2001: 47) dalam Wulandari (2014) return merupakan salah satu faktor yang memotivasi investor berinvestasi dan juga merupakan imbalan atas investor berinvestasi dan juga merupakan imbalan atas keberanian investor menanggung risiko atas investasi yang dilakukannya. Sementara return saham menurut Jogiyanto (2000: 107) merupakan hasil yang diperoleh dari investasi berupa return realisasi yang sudah terjadi maupun return ekspektasi yang belum terjadi namun diharapkan akan terjadi di masa mendatang. Dari pengertian diatas dapat disimpulkan bahwa return saham adalah imbalan yang diperoleh oleh investor atas keberaniannya menanggung risiko dari suatu dana atau modal yang ditanamkan pada suatu investasi di pasar modal berupa return realisasi dan return ekspektasi.

\section{Abnormal Return}

Abnormal return merupakan kelebihan dari return yang sesungguhnya terjadi terhadap return normal. Return normal merupakan return ekspektasi (return yang diharapkan oleh investor) dan merupakan return yang terjadi pada keadaan normal dimana tidak terjadi suatu peristiwa. Dengan adanya peristiwa tertentu, return normal akan naik (bila peristiwanya adalah peristiwa baik atau good news) atau akan turun bila peristiwanya adalah peristiwa jelek atau bad news). Hasil keseluruhannya adalah return sesungguhnya atau return nyata. Dengan demikian, return tidak normal (abnormal return) adalah selisih antara return sesungguhnya yang terjadi dan return ekspektasi (return normal).

Return sesungguhnya merupakan return yang 
terjadi pada waktu ke t yang merupakan selisih harga sekarang relatif terhadap harga sebelumnya. Sedangkan return ekspektasi merupakan return yang harus diestimasi. Brown dan Warner (1985) mengestimasi return ekspektasi menggunakan model estimasi mean-adjusted model, market model, dan market-adjusted model (Hartono 2005: 42) yaitu:

a. Mean-Adjusted Model

Model disesuaikan rata-rata (mean-adjusted model) ini mengasumsikan bahwa expected return bernilai konstan yaitu sama dengan rata-rata return realisasi sebelumnya selama periode estimasi (estimation period). Periode estimasi (estimation period) pada umumnya merupakan periode peristiwa. Periode peristiwa (event period) disebut juga periode pengamatan atau jendela peristiwa (event window).

b. Market Model

Perhitungan menggunakan model pasar (market model) ini dilakukan dengan dua tahapan:

- Membentuk model ekspektasi dengan menggunakan data realisasi selama periode estimasi.

- Menggunakan model ekspektasi ini mengestimasi expected return di periode jendela (window period). Model ekspektasi dapat dibentuk menggunakan teknik regresi OLS (Ordinary Least Square)

\section{c. Market-Adjusted Model}

Model disesuaikan pasar (market-adjusted model) mengasumsikan bahwa penduga yang terbaik untuk mengestimasi return suatu sekuritas adalah return indeks pasar pada saat tersebut. Model ini tidak memerlukan periode estimasi untuk membentuk model estimasi karena return sekuritas yang diestimasi adalah sama dengan return indeks pasar.

Abnormal return adalah return yang didapat investor yang tidak sesuai dengan pengharapan. Abnormal return adalah selisih antara return yang diharapkan dengan return yang didapatkan. Selisih return akan positifjika return yang didapatkan lebih besar dari return yang diharapkan atau return yang dihitung. Sedangkan return akan negatif jika return yang didapat lebih kecil dari return yang diharapkan atau return yang dihitung.

\section{Kerangka Konseptual}

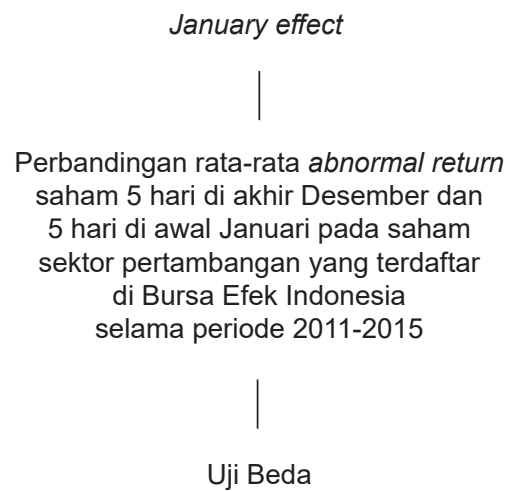

Gambar 1. Kerangka Konseptual

\section{Hipotesis Penelitian}

$\mathrm{H}_{0}$ : Diduga tidak terdapat perbedaan yang signifikan antara rata-rata abnormal return 5 hari di akhir Desember dan 5 hari di awal Januari pada saham sektor pertambangan yang terdaftar di Bursa Efek Indonesia selama periode 2011-2015.

$\mathrm{H}_{\mathrm{a}}$ : Diduga terdapat perbedaan yang signifikan antara rata-rata abnormal return 5 hari di akhir Desember dan 5 hari di awal Januari pada saham sektor pertambangan yang terdaftar di Bursa Efek Indonesia selama periode 20112015.

\section{METODELOGI PENELITIAN}

\section{Objek dan Lokasi Penelitian}

Objek pengamatan yaitu hanya terbatas pada data perkembangan harga saham (closing price) perusahaan pertambangan yang terdaftar di Bursa Efek Indonesia selama periode 2011-2015 dan data perkembangan IHSG selama periode pengamatan. Lokasi penelitian ini dilakukan di Bursa Efek Indonesia (BEI) dengan mengakses melalui website www.idx.co.id dan http://www.duniainvestasi.com.

\section{Jenis Penelitian}

Jenis penelitian ini adalah penelitian event study. Event study dapat digunakan untuk melihat reaksi pasar modal (dengan pendekatan pergerakan harga saham) terhadap suatu peristiwa tertentu. Event study sering digunakan sebagai alat 
untuk mengukur efisiensi pasar modal. Dalam menguji efisiensi pasar modal, event study digunakan untuk mengetahui apakah abnormal return yang terjadi setelah event tersebut diperkirakan sebelumnya (anticipated) dan digunakan untuk mengukur seberapa besar pengaruh event terhadap aktivitas di pasar modal.

\section{Populasi dan Sampel}

Populasi dalam penelitian ini adalah perusahaan sektor pertambangan yang terdaftar di Bursa Efek Indonesia periode 2011-2015 yaitu sejumlah 41 perusahaan. Sedangkan sampel sejumlah 35 perusahaan yang dipilih dengan menggunakan teknik purposive sampling, berdasarkan kriteriakrieria sebagai berikut:

1. Perusahaan pertambangan yang terdaftar di BEI selama periode 2011-2015.

2. Perusahaan memiliki data harga saham lengkap selama periode pengamatan, yaitu 5 hari akhir Desember dan 5 hari awal Januari.

3. Perusahaan tidak melakukan kegiatan-kegiatan luar biasa yang dapat mempengaruhi harga saham selama periode pengamatan, yaitu 5 hari akhir Desember dan 5 hari awal Januari.

\section{Teknik Pengumpulan Data}

Teknik pengumpulan data yang digunakan dalam penelitian ini adalah dengan cara dokumentasi. Menurut Arikunto (2002: 135) metode dokumentasi merupakan metode pengumpulan data yang bersumber pada benda-benda tertulis. Jenis data yang digunakan dalam penelitian ini adalah data kuantitatif yang bersifat sekunder yaitu data yang berasal dari pihak lain yang dikumpulkan ataupun diolah menjadi data untuk keperluan analisis, yang diperoleh melaui situs internet, buku atau sumber lain. Menurut waktu pengumpulannnya, data yang digunakan dalam penelitian ini digolongkan ke dalam pooled data, yaitu kombinasi antara data time series dan data cross section.

\section{Definisi Operasional Variabel Abnormal Return}

Abnormal return adalah return yang didapat investor yang tidak sesuai dengan pengharapan. Abnormal return adalah selisih return dengan expected return (return ekspektasi). Penelitian ini menggunakan Market Adjusted Model untuk mengestimasi return ekspektasinya. Adapun langkah-langkah untuk menghitung abnormal return adalah sebagai berikut:

\section{a. Return Saham}

Return saham didefinisikan sebagai perubahan harga saham yang dihitung dengan mengurangkan harga saham pada waktu tertentu dengan harga saham pada periode sebelumnya. Adapun rumus return adalah sebagai berikut (Dewi dan Putra, 2013):

$$
\mathbf{R}_{\mathrm{it}}=\frac{\mathbf{P}_{\mathbf{t}}-\left(\mathbf{P}_{\mathrm{t}-1)}\right)}{\mathbf{P}_{(\mathrm{t}-1)}}
$$

Dimana :

$\mathrm{R}_{\mathrm{it}}$ : Return individual saham i pada saat $\mathrm{t}$

$\mathrm{P}_{\mathrm{t}}$ : Harga penutupan saham i pada saat $\mathrm{t}$

$\mathrm{P}_{\mathrm{t}-1}$ : Harga penutupan saham i pada saat $\mathrm{t}-1$

\section{b. Expected Return}

Expected return merupakan return yang diharapkan akan terjadi dimasa yang akan datang. Expected return dihitung dengan menggunakan indeks pasar karena menurut Market Adjusted Model penduga terbaik untuk mengestimasi return suatu sekuritas adalah indeks pasar pada saat hari itu. Maka dengan model ini tidak perlu menggunakan estimation period karena return efek yang diestimasi sama dengan return indeks pasar (Hartono, 2008). Indeks pasar yang digunakan adalah IHSG.Rumus untuk mencari return pasar adalah (Dewi dan Putra, 2013):

$$
\mathbf{R}_{\mathrm{mt}}=\frac{\text { IHSG }_{\mathrm{t}}-\text { IHSG }_{\mathrm{t}-1}}{\text { IHSG }_{\mathrm{t}-1}}
$$

Dimana:

$\mathrm{R}_{\mathrm{mt}}$ : Tingkat return pasar pada saat $\mathrm{t}$

IHSG $_{t}$ : Indeks Harga Saham Gabungan pada saat $\mathrm{t}$ $\mathrm{IHSG}_{\mathrm{t}-1}$ : Indeks Harga Saham Gabungan pada saat $\mathrm{t}-1$

\section{c. Abnormal Return}

Karena expected return $=$ return pasar, maka $\mathrm{E}\left(\mathrm{R}_{\mathrm{it}}\right)=\mathrm{E}\left(\mathrm{R}_{\mathrm{mt}}\right)$.

Rumus abnormal return adalah sebagai berikut (Hartono, 2005: 43): 


$$
\operatorname{AbR}_{\text {it }}=\mathbf{R}_{\mathrm{it}}-\mathbf{E}\left(\mathbf{R}_{\mathrm{it}}\right)
$$

Dimana:

$\mathrm{AbR}_{\mathrm{it}}$ : Abnormal return sekuritas ke-i pada periode peristiwa ke-t

$\mathrm{R}_{\mathrm{it}} \quad$ : Return yang terjadi untuk sekuritas ke-i pada periode peristiwa ke-t

$\mathrm{E}\left(\mathrm{R}_{\mathrm{it}}\right)$ : Expected return sekuritas ke-i pada periode peristiwa ke-t

d. Rata-Rata Abnormal Return atau Average Abnormal Return (AAR)

Rumus Average Abnormal Return adalah sebagai berikut (Hartono, 2005: 49):

$$
\operatorname{AARt}=\frac{\sum_{i=1}^{k} A R i, t}{\mathbf{K}}
$$

Dimana:

AARt : Average Abnormal Return pada hari ke- $\mathrm{t}$

AR i,t : Abnormal Return untuk sekuritas ke-i pada hari ke $\mathrm{t}$

$\mathrm{K}$ : Jumlah sekuritas yang terpengaruh oleh pengumuman peristiwa.

\section{Uji Asumsi Klasik}

\section{Uji Normalitas Data}

Uji normalitas digunakan untuk mengetahui apakah populasi data berdistribusi normal atau tidak. Uji ini biasanya digunakan untuk mengukur data berskala ordinal, interval ataupun rasio. Untuk mendeteksi normalitas data dapat dilakukan dengan uji metode Kolmogorov-Smirnov Test (Priyatno, 2010: 71). Jika analisis menggunakan metode parametrik maka persyaratan normalitas harus terpenuhi, yaitu data berasal dari distribusi normal. Jika data tidak berdistribusi normal, maka metode yang digunakan adalah statistik non parametrik. Dasar pengambilan keputusan untuk menentukan normalitas data adalah sebagai berikut:

a. Jika probabilitas (Asymp.Sig) $<0,05$ maka data tidak berdistribusi normal

b. Jika probabilitas (Asymp.Sig) $>0,05$ maka data berdistribusi normal

Pengujian ini menggunakan program SPSS 16.0 (Subardi, 2014).

\section{Pengujian Hipotesis Uji Beda}

Pengujian hipotesis dalam penelitian ini ditentukan berdasarkan hasil dari uji normalitas data, untuk dapat menentukan alat uji apa yang paling sesuai digunakan. Apabila data berdistribusi normal maka digunakan uji parametrik Paired Sample T-Test. Sementara apabila data tidak berdistribusi normal maka digunakan uji non-parametrik yaitu Wilcoxon Signed Rank Test. Kedua model uji beda tersebut digunakan untuk menganalisis model penelitian pre-post atau sebelum dan sesudah. Uji beda digunakan untuk mengevaluasi perlakuan (treatment) tertentu pada satu sampel yang sama pada dua periode pengamatan yang berbeda (Pramana, 2012).

\section{Paired Sample T-test}

Paired sample t-test digunakan untuk menguji perbedaan dua sampel yang berpasangan. Sampel yang berpasangan diartikan sebagai sebuah sampel dengan subjek yang sama namun mengalami dua perlakuan yang berbeda pada situasi sebelum dan sesudah proses (Santoso, 2001). Dasar pengambilan keputusan untuk menerima atau menolak $\mathrm{H}_{0}$ pada uji paired sampel t-test adalah:

a. Jika probabilitas (Asymp.Sig) $<0,05$ maka $\mathrm{H}_{0}$ ditolak dan $\mathrm{H}_{\mathrm{a}}$ diterima.

b. Jika probabilitas (Asymp.Sig) $>0,05$ maka $\mathrm{H}_{0}$ diterima dan $\mathrm{H}_{\mathrm{a}}$ ditolak.

2. Wilcoxon Signed Rank Test

Wilcoxon signed rank test merupakan uji non parametrik yang digunakan untuk menganalisis data berpasangan karena adanya dua perlakuan yang berbeda (Pramana, 2012). Dasar pengambilan keputusan untuk menerima atau menolak $\mathrm{H}_{0}$ pada uji wilcoxon signed rank test adalah:

a. Jika probabilitas (Asymp.Sig) $<0,05$ maka $\mathrm{H}_{0}$ ditolak dan $\mathrm{H}_{\mathrm{a}}$ diterima.

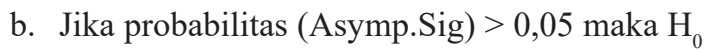
diterima dan $\mathrm{H}_{\mathrm{a}}$ ditolak.

\section{HASIL DAN PEMBAHASAN}

\section{Uji Asumsi Klasik \\ Uji Normalitas Data}

Uji normalitas data dalam penelitian ini menggunakan metode Kolmogorov Smirnov Test yang 
dioperasikan dengan SPSS 16.0. Jika probabilitas (Asymp.Sig) < 0,05 maka data tidak berdistribusi normal sebaliknya jika probabilitas (Asymp.Sig) $>0,05$ maka data berdistribusi normal. Hasil pengujian normalitas data dapat ditunjukkan pada Tabel 2 berikut.

Tabel 2

Hasil Uji Normalitas Data

One-Sample Kolmogorov-Smirnov Test

\begin{tabular}{llrr}
\hline & & Desember & \multicolumn{1}{c}{ Januari } \\
\hline $\mathrm{N}$ & & 140 & 140 \\
Normal & Mean & -.000996 & .002010 \\
Parameters $^{\text {a }}$ & Std. & .0152176 & .0206044 \\
& Deviation & .175 & .180 \\
Most Extreme & Absolute & .175 & .180 \\
Differences & Positive & -.130 & -.156 \\
& Negative & 2.076 & 2.133 \\
Kolmogorov-Smirnov Z & .000 & .000 \\
Asymp. Sig. (2-tailed) & \multicolumn{3}{c}{} \\
\hline a. Test distribution is Normal. & \\
Sumber: Data Sekunder (diolah), 2017
\end{tabular}

Berdasarkan hasil uji normalitas data pada tabel di atas, dapat dilihat bahwa nilai Asymp. Sig $(0,000)<\alpha=0,05$ maka data berdistribusi tidak normal. Oleh karena itu digunakan uji non-parametrik yaitu Wilcoxon Signed Rank Test.

\section{Pengujian Hipotesis}

Melalui pengujian persyaratan data yang telah dinyatakan tidak normal maka pengujian hipotesis akan menggunakan Wilcoxon Signed Rank Test untuk mengetahui ada tidaknya perbedaan yang signifikan antara rata-rata abnormal return 5 hari di akhir Desember dan 5 hari di awal Januari pada saham sektor pertambangan yang terdaftar di Bursa Efek Indonesia selama periode 2011-2015.

Hasil uji Wilcoxon Signed Rank Test disajikan dalam Tabel 3 berikut.

Tabel 3

Hasil Uji Wilcoxon Signed Rank Test

Test Statistics

\begin{tabular}{lr}
\multicolumn{2}{c}{ Jest Statistics $^{\text {J }}$} \\
\hline Z & $-3.113^{\mathrm{a}}$ \\
Asymp. Sig. (2-tailed) & .002 \\
\cline { 2 - 2 } a. Based on negative ranks. & \\
b. Wilcoxon Signed Ranks Test & \\
Sumber : Data Sekunder (diolah), 2017
\end{tabular}

Dari tabel di atas dapat dilihat bahwa nilai
Asymp.Sig $(0,002)<0,05$. Maka $\mathrm{H}_{0}$ ditolak dan $\mathrm{H}_{\mathrm{a}}$ diterima. Hal ini menandakan bahwa terdapat perbedaan yang signifikan antara rata-rata abnormal return 5 hari di akhir Desember dan 5 hari di awal Januari pada saham sektor pertambangan yang terdaftar di Bursa Efek Indonesia selama periode 2011-2015.

\section{PEMBAHASAN}

Hasil uji normalitas menunjukkan bahwa penelitian ini memiliki data yang tidak normal sehingga menggunakan alat uji non-parametrik yaitu Wilcoxon Signed Rank Test. Tidak normalnya data disebabkan karena banyaknya perusahaan yang tidak melakukaan aktifitas perdagangan sehingga banyak perusahaan yang tidak menghasilkan return (Listyorini, 2016). Berdasarkan hasil uji Wilcoxon Signed Rank Test terdapat perbedaan yang signifikan antara rata-rata abnormal return 5 hari di akhir Desember dan 5 hari di awal Januari yang menunjukkan bahwa terdapat fenomena January effect pada saham sektor pertambangan yang terdaftar di Bursa Efek Indonesia selama periode 2011-2015.

Dalam penelitian ini, January effect terjadi karena adanya kenaikan harga saham pada awal tahun. Dengan meningkatnya harga saham pada saat pergantian tahun, maka return yang dihasilkan pun akan ikut meningkat. Namun tingginya return actual pada saham-saham yang tergolong ke dalam sektor pertambangan tidak di ikuti oleh pergerakan harga saham perusahaan lain di dalam IHSG, yang mengakibatkan return pasar atau return IHSG pada Bursa Efek Indonesia lebih rendah, sehingga diperoleh abnormal return yang lebih tinggi dari yang diekspektasikan para investor di awal tahun. Asumsi lain terjadinya January effect adalah karena adanya keinginan perusahaan untuk terlihat lebih baik yang tercermin dalam laporan keuangan tahunan, sehingga manajer perusahaan menjual saham-saham yang dianggap mempunyai nilai kecil pada akhir tahun dan akan membelinya kembali pada awal tahun.

Hasil penelitian ini mendukung penelitian sebelumnya yang dilakukan oleh Tasman dkk (2015) pada saham yang masuk ke dalam Main Board Index (MBX) di Bursa Efek Indonesia 
periode Desember 2009 sampai Januari 2014 Penelitian tersebut menyatakan bahwa adanya perbedaan abnormal return di awal tahun yang menandakan bahwa salah satu fenomena yang dapat mengakibatkan para investor memperoleh abnormal return pada pasar efisien telah terjadi, yaitu fenomena January effect.

Namun hasil penelitian ini tidak sejalan dengan penelitian Wijaya dkk (2013) pada sektor manufaktur di Bursa Efek Indonesia periode 2010-2012. Penelitian tersebut menyatakan bahwa tidak terdapatnya pola dan perbedaan rata-rata abnormal return pada saat sebelum dan sesudah January effect pada saham perusahaan di sub sektor manufaktur di bagian sektor industri barang konsumsi selama 3 (tiga) tahun berturutturut dari periode 2010-2012, sehingga fenomena January effect tidak terjadi.

\section{KESIMPULAN}

Berdasarkan hasil pengujian hipotesis dan pembahasan, maka dapat disimpulkan bahwa terdapat perbedaan yang signifikan antara rata-rata abnormal return 5 hari di akhir Desember dan 5 hari di awal Januari yang menunjukkan bahwa terdapat fenomena January effect pada saham sektor pertambangan yang terdaftar di Bursa Efek Indonesia selama periode 2011-2015.

\section{SARAN}

Bagi para investor yang akan melakukan investasi saham di Bursa Efek Indonesia diharapkan untuk dapat aktif dalam mencari maupun menerima informasi khususnya pola pergerakan saham di awal tahun dan memperhatikan adanya fenomena January effect, yaitu dengan cara mencerna dan mengelola informasi tersebut dengan baik agar dapat menghasilkan strategi yang mampu memberikan investor peluang untuk memperoleh return yang lebih tinggi.

Bagi peneliti selanjutnya, diharapkan dapat memperluas penelitian terkait dengan January effect, return, abnormal return, dan faktor-faktor lain yang berkaitan dengan January effect serta memperluas periode pengamatannya. 


\section{REFERENSI}

Alwi, Iskandar. (2003). Pasar Modal Teori dan Aplikasi. Jakarta: Nasindo Indonesia.

Arikunto, Suharsimi. (2002). Prosedur Penelitian: Suatu Pendekatan Praktek. Edisi Revisi V. Jakarta: PT. Rineka Cipta.

Audina, Mellina dan Kazia Laturette. (2017). January Effect pada Sektor Property, Real Estate, dan Building Construction di BEI. Universitas Ciputra Jakarta.

Darmadji, Tjiptono dan Hendy M. Fakhruddin. (2001). Pasar Modal di Indonesia. Jakarta: Salemba Empat.

Dewi, Ni Putu Sentia dan I Nyoman Wijana Asmara Putra. (2013). Pengaruh Pengumuman Right Issue pada Abnormal Return dan Volume Perdagangan Saham. Universitas Udayana, Bali.

Fahmi, Irham. (2012). Manajemen Investasi: Teori dan Soal Jawab. Jakarta: Salemba Empat.

Fitriyani, Indah dan Maria M. Ratna Sari. (2012). Analisis January Effect pada Kelompok Saham Indeks LQ-45 di Bursa Efek Indonesia Tahun 2009-2011. Universitas Udayana, Bali.

Halim, Abdul. (2005). Analisis Investasi. Jakarta: Salemba Empat.

Hartono, Jogiyanto. (2005). Pasar Efisien Secara Keputusan. Jakarta: PT. Gramedia Pustaka Utama. (2008). Teori Portofolio dan Analisis Investasi. Yogyakarta: BPFE-UGM.

http://britama.com diakses 7 Agustus 2017

http://finance.yahoo.com diakses 25 Januari 2017

http://www.duniainvestasi.com/ diakses 25 Januari 2017

http:/www.idx.co.id diakses 20 Januari 2017

http://www.sahamok.com diakses 20 Januari 2017

Jogiyanto, H.M. (2000). Teori Portofolio dan Analisis Investasi. Yogyakarta: BPFE.

Lukmansyah, Shella Andianti. (2015). Analisis Abnormal Return Saham Sebelum dan Sesudah Peristiwa January Effect (Studi pada Perusahaan-Perusahaan yang Termasuk ke dalam Indeks LQ-45 di Bursa Efek Indonesia Periode 2010-2014. Skripsi. Universitas Pasundan Bandung.

Maliasari, Karina. (2014). Pengaruh January Effect dan Rogalski Effect Terhadap Abnormal Return Saham dan Trading Volume Activity (Studi pada Perusahaan LQ-45 yang Terdaftar di Bursa Efek Indonesia). Universitas Brawijaya, Malang.

Martalena dan Maya Malinda. (2011). Pengantar Pasar Modal. Yogyakarta: ANDI. 
Mardhiyah, Siti. (2014). Pengaruh Bulan Perdagangan Terhadap Return Saham: Pengujian January Effect di Indeks Harga Saham Liquidity 45 (Studi pada Perusahaan yang Bergerak di Bidang Keuangan Perbankan yang Tercatat di LQ-45 Selama Periode 2004-2012). Universitas Brawijaya, Malang.

Pertiwi, Putri Cahaya dan Deannes Isynuwardhana. (2014). January Effect pada Perusahaan LQ-45 di Bursa Efek Indonesia Periode 2009-2013. Universitas Telkom Bandung.

Pramana, Andi. (2012). Analisis Perbandingan Trading Volume Activity dan Abnormal Return Saham Sebelum dan Sesudah Pemecahan Saham (Studi Kasus pada Perusahaan yang Terdaftar di Bursa Efek Indonesia Periode 2007-2011). Universitas Diponegoro, Semarang.

Prasetyo, Hari. (2006). Analisis Pengaruh Hari Perdagangan Terhadap Return, Abnormal Return, dan Volatilitas Return Saham (Studi Pada LQ-45 Periode Januari - Desember 2005). Tesis. Universitas Diponegoro Semarang.

Pratomo, Agus Wahyu. (2007). January Effect dan Size Effect pada Bursa Efek Jakarta (BEJ) Periode 1998-2005. Tesis. Universitas Diponegoro Semarang.

Priyatno, Duwi. (2010). Paham Analisa Statistik Data dengan SPSS. Yogyakarta: Media Kom.

Purba, Fransisko dan Siti Ragil Handayani. (2017). Analisis Perbedaan Reaksi Pasar Modal Indonesia Sebelum dan Sesudah Peristiwa Non Ekonomi (Studi pada Peristiwa Politik Pilkada DKI Jakarta 2017 Putaran Kedua). Universitas Brawijaya, Malang.

Purwati, Analia Ika. (2015). Studi Pengaruh Hari Perdagangan Terhadap Return Saham pada BEI: Pengujian Week Four Effect dan Rogalski Effect. Skripsi. Universitas Negeri Semarang.

Qoribulloh, A. Rizal. (2013). Pengaruh Rasio Keuangan Terhadap Harga Saham pada Perusahaan Manufaktur yang Terdaftar di Bursa Efek Indonesia Tahun 2011. Skripsi. Universitas Negeri Yogyakarta.

Rafela, Paramitha. (2016). Analisis Perbedaan Abnormal Return Sebelum dan Sesudah Pengumuman Peringkat Obligasi di Indonesia. Universitas Lampung, Bandar Lampung.

Rahmadi, Latif. (2010). Pengaruh Kinerja Keuangan terhadap Harga Saham pada Perusahaan Perbankan yang Terdaftar di Bursa Efek Indonesia Periode 2004-2008. Skripsi. Universitas Negeri Yogyakarta.

Rodoni, Ahmad dan Othman Yong. (2002). Analisis Investasi dan Teori Portfolio. Jakarta: PT. RajaGrafindo Persada.

Samsul, Mohamad. (2006). Pasar Modal dan Manajemen Portofolio. Jakarta: Erlangga.

Sanjaya, Moch Jufan. (2012). Analisis January Effect pada Perusahaan yang Terdaftar di LQ-45 sebagai Bahan Pengembalian Keputusan pada Bursa Efek Indonesia Periode 2007-2011. Tesis. Universitas Islam Negeri Maulana Malik Ibrahim Malang. 
Santoso, Singgih. (2001). SPSS Versi 10 Mengelola Data Statistic Secara Professional. Jakarta. Gramedia.

Sari, Swasti Tyas. (2007). Pengaruh Kondisi Keamanan dalam Negeri Terhadap Harga Saham di Bursa Efek Jakarta (Event Study Peristiwa Bom Kuningan). Skripsi. Universitas Muhammadiyah, Surakarta.

Subardi, Rahmat Andi. (2014). Analisis Abnormal Return Saham, Volume Perdagangan Saham dan Volatilitas Harga Saham Sebelum dan Sesudah Peristiwa Stock Split (Studi pada Perusahaan yang Go Public di Bursa Efek Indonesia Periode 2010-2012). Skripsi. Universitas Lampung.

Sugiyono. (2012). Metode Penelitian Bisnis (Pendekatan Kuantitatif, Kualitatif, dan R\&D). Bandung. Alfabeta.

. (2012). Statistika untuk Penelitian. Bandung: Alfabeta.

Sujarweni, V. Wiratna. (2015). Metodelogi Penelitian Bisnis dan Ekonomi. Yogyakarta: Pustaka Baru Press.

Sulastri, Deci Jani. (2013). Analisis Abnormal Return Saham Sebelum dan Sesudah Peristiwa January Effect (Studi pada Perusahaan LQ-45 di Bursa Efek Indonesia Periode 2007-2012. Skripsi. Universitas Widyatama Bandung.

Syari, Lisa Revita. (2012). Analisis January Effect pada Saham LQ-45 Sektor Perbankan di Bursa Efek Indonesia (BEI) Periode 2004-2009. Skripsi. Universitas Lampung.

Tasman, Abel, Rosyeni Rasyid, dan Ika Putriana Timuria. (2015). Analisis January Effect: Studi Empiris pada Main Board Index (MBX) di Bursa Efek Indonesia. Universitas Negeri Padang.

Werastuti, Desak Nyoman Sri. (2012). Anomali Pasar pada Return Saham : The Day of Week Effect, Week Four Effect, Rogalsky Effect, dan January Effect. Universitas Pendidikan Ganesha Bali.

Widiyanto, Mikha Agus. (2013). Statistika Terapan. Jakarta. PT Elex Media Komputindo.

Wijaya, Hadi, Dinnul Alfian Akbar dan Rini Aprilia. (2013). Analisis January Effect pada Sektor Manufaktur di Bursa Efek Indonesia (BEI). STIE MDP Palembang.

Wulandari, Ayu. (2014). Analisis Fenomena January Effect pada Saham LQ-45 yang Listing di BEI Periode 2009-2013. Universitas Negeri Padang.

Wulandari, Meri. (2013). Anomali Pasar Bulan Perdagangan Terhadap Return Saham dan Abnormal Return" (Studi Kasus Saham-Saham Sektor Basic Industry And Chemicals, Miscallaneus, and Consumer Goods yang Terdaftar di Bursa Efek Indonesia (BEI) Periode 2007-2012). Skripsi. Universitas Islam Negeri Syarif Hidayatullah Jakarta.

Yani, Aulia Rahma. (2013). January Effect dan Size Effect pada Perusahaan yang Terdaftar di Bursa Efek Indonesia. Universitas Brawijaya Malang.

Yanti, Firga. (2012). Pengujian Abnormal Return Saham Sebelum dan Sesudah Peluncuran Indeks Saham Syariah Indonesia (ISSI). Universitas Negeri Padang. 